Englund Dimitrova, Birgitta \& Maureen Ehrensberger-Dow (2018). Cognitive Space: Exploring the Situational Interface. In: Ehrensberger-Dow, Maureen \& Birgitta Englund Dimitrova (eds). Exploring the Situational Interface of Translation and Cognition. [Benjamins Current Topics 101]. Amsterdam: John Benjamins. 1-18. https://doi.org/10.1075/bct.101.01eng

\title{
Cognitive Space: Exploring the Situational Interface
}

\author{
Birgitta Englund Dimitrova, Stockholm University \\ Maureen Ehrensberger-Dow, Zurich University of Applied Sciences
}

\section{Introduction}

Until relatively recently, there has been an invisible line in translation and interpreting (T\&I) studies between cognitive research (e.g., into mental processes, attitudes) and sociological research (e.g., concerning organization, status, institutions). The guest editors of this special issue both have a background in cognitive, process-oriented studies of translation and interpreting (e.g., Ehrensberger-Dow 2014; Ehrensberger-Dow and Massey 2013; Englund Dimitrova and Hyltenstam 2000; Englund Dimitrova 2005), but the question of the situatedness of the cognitive act of translation has come increasingly into focus in our own work and research in recent years. In the collection of articles edited by Ehrensberger-Dow et al. (2013/2015), these aspects were addressed, albeit with more weight on the cognitive side. In the present volume, the balance is shifted to a greater concern for situational aspects. ${ }^{1}$

Most of the papers of this special issue are situated within the domain of professional translation, whose practices have undergone profound changes during the last decades. ${ }^{2}$ In the traditional view, a translator did her work-most were women-in a solitary fashion, often in domestic settings, emerging after a long time from her desk (or kitchen table) with a finished translation in hand. The most commonly used aids were dictionaries in the form of books. Contacts and collaboration with the outer world in the work process were limited to the moments when translation commissions were received and delivered, and to any consultations with domain-specific experts that were deemed necessary in order to solve problems, such as terminology, whose solutions could not be found in the written documentation that was readily available.

\footnotetext{
${ }^{1}$ This special issue is the result of a panel at the IATIS conference in Belo Horizonte, Brazil, in July 2015 and of a subsequent call for papers addressing theoretical, methodological, and/or empirical questions at the interface between the cognitive and situational levels of translation.

${ }^{2}$ Of course, the many kinds of non-professional translation and interpreting (e.g., volunteers, fan-subbing, etc.) are equally relevant and important to study from the cognitive and situational perspectives. For discussions of non-professional translation and interpreting, see Angelelli (2014), Antonini (2010), O’Hagan (2011), or SusamSaraeva and Pérez (2012).
} 
The picture today is quite different and, in this introduction, we will present some background on recent developments in professional translation and interpreting which have potential impacts on both the cognitive and situational levels. To provide an appropriate context for the contributions in this special issue, our introduction focuses in particular on three different perspectives: the introduction of information and communication technology (ICT) into the workflow, the overall organization of translation and interpreting work, and the work situation for individual translators and interpreters.

\section{Impact of ICT on translation and interpreting activities}

The claim has been made that ICT has fundamentally changed the cognitive activity of translation (e.g., Pym 2011), just as it has changed the way that translators (not to mention most knowledge workers and the rest of the world; see Palvalin, Lönnqvist, and Vuolle 2013) interact with their clients, employers, and colleagues (e.g., Eurofound 2015; UN 2011). In fact, the impact of technology on translation activities began with the development of writing and continued through manual, electric, and electronic typewriters to text editing programs on personal computers, which in turn led to the plethora of tools available to professionals (for an overview, see García 2009 or Enríquez 2013). Technology has become so entrenched in the practice that it is hard to imagine translation without it, as explained below.

\footnotetext{
Technology is not an option in today's professional world; it is a necessity. Years ago one talked about Computer-Aided Translation (CAT). That now seems a redundancy. Virtually all translating is aided by computers. Further, the most revolutionary tools are quite probably the everyday ones that are not specific to translation: Internet search engines, spell checkers, search and replace functions, and revision tools have had a huge impact on all forms of written communication.

(Biau and Pym 2006, 17)
}

Consecutive interpreting has long relied on manual note-taking, which now exists in parallel with mobile devices such as tablets and digital tools (e.g., the smart pen; see Orlando 2014). The development of radio, telephony, microphones, and headphones at the beginning of the 20th century ushered in the era of simultaneous and conference interpreting as we know them (e.g., Chernov 2016). With respect to equipment and conditions, international standards have long been in place for simultaneous interpreting (ISO 2603:1998 for built-in and ISO 4043:1998 for mobile booths). For logistical and economic reasons, however, pressure is growing for interpreting to be provided remotely through video and Internet links.

The past couple of decades have seen an explosion in language technology along with concomitant pressure for translators and interpreters to acquire advanced ICT skills. Tools 
related to terminology management, computer-assisted translation (CAT), translation memories (TM), translation environment (TEnT; see Zetsche 2007), machine translation (MT), and also computer-assisted interpreting (CAI; see Costa, Corpas, and Durán 2014) are available to aid T\&I activities, and professionals are expected to be familiar with them. This has been made explicit in the European standard for translation services (EN15038:2006) as well as in the newer international standard (ISO 17100:2015), which specifies that language technology tools and information resources are an integral part of the professional translation process. Gouadec $(2007 / 2010,156)$ has gone as far as to claim, on the basis of a survey of job ads, that ICT skills might take precedence over language skills for some employers.

The impact of this increased use of technology has become the focus of discussion in translation studies and the subject of recent empirical research about cognitive effort. For example, Pym $(2011,1)$ claims that translation technologies "are altering the very nature of the translator's cognitive activity, social relations, and professional standing”. One of the most obvious ways that this is happening is the extension or outsourcing of memory that terminology and TM systems essentially provide interpreters and translators with. Pym (2011, 2) warns, however, that this might "undercut intuition" and be at the cost of increasing complexity for decision-making since the systems offer various choices that then have to be evaluated and rejected or accepted as appropriate.

A more optimistic view of the cognitive benefits of ICT is presented by O’Brien (2012, 107) in her discussion of translation as a form of human-computer interaction: relief from the tedium of re-translating repetitive content, of having to remember the approved terminology, and of checking for consistency (see also Austermühl 2001; 2011 or Risku 2007). Nevertheless, there can be cognitive costs in the form of having to correct machine-induced errors and ensuring cohesion and coherence. Risku (2007) argues that the latter is beyond the scope of language technology in the foreseeable future because it relies on creativity to choose the best solution from alternatives, which has always been the 'added value' of human translation. She points out that the profile of professional translation is changing along with technological innovation and that new opportunities are opening up, but that translators need to be properly prepared for these (see also Pym 2013).

The importance of training is highlighted by research suggesting that language technology such as TM can influence translators by making them more likely to translate sentence by sentence (cf. Bowker 2005; Dragsted 2006; Jiménez 2009; Torres et al. 2010). This forms part of the growing body of evidence that translators adjust their cognitive processes to fit the constraints of the language technology instead of the converse. This has 
been demonstrated by many researchers with respect to the use of TM (e.g., Alves and Liparini Campos 2009; Christensen 2011; Christensen and Schjoldager 2010; EhrensbergerDow and Massey 2014; Elimam 2007; LeBlanc 2013; O’Brien, O’Hagan, and Flanagan 2010; Screen 2016) as well as to post-editing MT (Mesa 2014; Moorkens and O’Brien 2013), integration of MT in TM (Teixeira 2014), and to the usability of tools in general (HansenSchirra 2012; Taravella and Villeneuve 2013). In a recent international survey of 1,850 translators (Ehrensberger-Dow et al., forthcoming), almost all of the respondents who used at least one CAT tool found them helpful at least some of the time. Yet more than half of those respondents seemed to have adjusted to their tools, using the default settings instead of availing themselves of the possibilities to customize them, despite almost $60 \%$ of them saying that they found things about their CAT tools irritating.

This irritation with the intensive human-computer interactions that characterize modern translation has parallels in the stress associated with various forms of professional interpreting that involve heavy use of technology, such as conference (e.g., Kurz 2002), remote (e.g., Roziner and Shlesinger 2010), and video relay service interpreting (e.g., Bower 2015). Problems with technology, such as delays in computer responsiveness, can negatively affect task performance in various domains and potentially contribute to stress (e.g., Chevalier and Kicka 2006; Szameitat et al. 2009; Tuch et al. 2009). The sheer proliferation of tools can also contribute to cognitive overload or disorientation and affect cognitive flow (see EhrensbergerDow and O’Brien 2015 for a discussion).

The most recent European language industry report (Elia 2016) highlights the importance of technology tools at the modern translation workplace: 93\% of the 445 language service providers from 35 countries that responded to the survey use CAT tools, and $84 \%$ use some kind of workflow management system. To a lesser extent, some form of MT (41\%), quality control automation (38\%), and voice recognition (10\%) are also part of the translation workflow. Despite Gambier's $(2016,890)$ observation that translation is “going digital”, there are clearly still large differences in the degree of technologization and the workflows of various workplaces. The socio-technical systems that translators and interpreters are embedded in can be considered an interface between the cognitive and situational aspects of their professional activity.

Interpreting has long been identified as a socially-situated activity (e.g., Angelelli 2004; Berk Seligson 1990; Wadensjö 1998), and this conceptualization is becoming increasingly dominant in understanding translation as well. Risku (2002) points out that notions of situated translation can be traced to Hönig and Kussmaul (1982), Reiss and Vermeer (1984), and 
Holz-Mänttäri (1984) and that they differ from language-oriented and text-oriented understanding of translation in their focus on the situational function, action, and pragmatics. According to Risku (2002, 525), “[t]ranslators create a means of communicating in a specific target situation.” In more recent work, Risku (2010; 2014) and her colleagues (e.g., Risku and Dickinson 2009; Risku, Rogl and Pein-Weber 2016; Risku and Windhager 2013/2015) have been exploring translation work as an example of situated, extended cognition within a complex, dynamic network and socio-cultural context. From their perspective, language technology is an important element of both. Alonso and Calvo $(2015,152)$ go even farther and formulate what they refer to as a "trans-human translation hypothesis" - an extreme view of the impact of ICT on translation-in which there is a "mutual interplay between human translators and their tools” and a merging of situated cognition with ubiquitous computing.

\section{Organization of translation and interpreting work}

Translation and interpreting work is performed in various types of organizations. Specialized companies, usually referred to as language service providers (LSPs), have the main purpose of providing translation, interpreting, and other language-related services such as localization. They sell their products and services to two types of customers: on the one hand, to those traditionally viewed as the end users-ranging from large governmental agencies, business firms, and public agencies to private persons in need of translation of documents-and, on the other hand, to other LSP firms, in which case the seller has been subcontracted. One and the same LSP firm can also have both kinds of customers. LSP companies are of varying size, in terms of number of employees and revenue, from one-person businesses to large companies with thousands of employees, often in various offices in many different countries (see Kelly and DePalma 2012). To ensure good practices, standards have been introduced for translation services (e.g., EN15038:2006, now superseded by ISO 17100:2015). At the time of writing, an international standard is in place for community interpreting (ISO 13611:2014) but one for interpreting service providers is still under consideration by the various stakeholders. ${ }^{3}$

Translation and interpreting work is also done in organizations, companies, and institutions whose core activity is something other than providing language services, but which have their own service to cater for their internal needs. Examples include the European Commission, the United Nations, and government agencies in countries with official bi- or multilingualism as well as corporations all over the world.

\footnotetext{
${ }^{3}$ A draft can be viewed at http://www.fit-ift.org/wp-content/uploads/2014/12/isotc37sc5_N0125_CD188411_Interpreting-General-requirements-and-recommendations-Part-1-Overview-terms-and-definitions.pdf.
} 
The translation industry at large is characterized by a high degree of subcontracting or outsourcing of the actual translation work (see Kuznik and Verd 2010). For example, the most recent report by the Common Sense Advisory (DePalma et al. 2015) predicted that the market for outsourced language services and related technogologies would reach over USD 38 billion in 2015. Translation and interpreting is outsourced not only by LSPs, as indicated above, but also by some large language services. Lafeber (2012, 3; quoting DGT 2011) says that about $28 \%$ of translation work of the European Commission is done by external contractors and that for the UN the corresponding figure is about 20\% (see DGACM 2011). The situation seems quite similar for interpreting in the institutions, since the most recent statistics from the European Commission's Directorate General for Interpretation indicate that it has 560 staff interpreters and over 3,000 accredited freelancers who worked at least 10 days for them in the previous year (DGI 2015).The sub-contractors can be either individuals, working through their own one-person businesses as freelancers, or other LSP firms (see above). Dunne (2012, 145) provides a three-tier illustration of this organizational structure, which he calls the "the language industry subcontracting chain”, with the three elements Client (translation buyer/end user), LSP, and Freelancer (individual translator, single language vendors, specialized providers; see Figure 1).

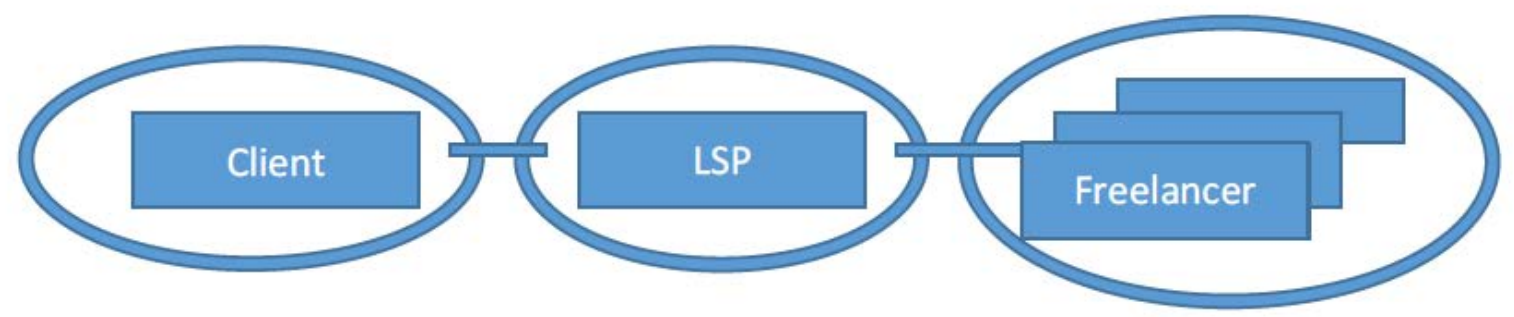

Figure 1. The language industry subcontracting chain (from Dunne 2012, 145)

Englund Dimitrova (2015a) pointed out that the LSP part of this chain can be divided into several subsequent steps by further outsourcing in a hierarchical fashion, until the job finally reaches the actual translator or interpreter.

From an organizational perspective, a picture of hierarchical relations emerges. End users can cater for their translation needs basically in one of two ways: by organizing a translation and/or interpreting department within the organization and hiring the appropriately trained employees; or by buying the service from one or several language service providers. In the latter case, it can be assumed that the buyer will prefer an LSP that can cater for all 
needs in terms of language combinations, text types, special services (e.g., terminology management), etc.

Translation and interpreting require specialized knowledge, but it is in the commercial interest of any LSP to be able to offer a maximally wide range of services within its chosen field of activity at the lowest possible cost. Hiring translators and interpreters to cope with all possible domains, text types, and language combinations would be an expensive business model. It would also be connected with high risk-taking, since the demand for a particular type of translation and language combination may suddenly drop, rendering the translators and interpreters who have been hired to do it less useful for the company. Outsourcing translation and interpreting tasks by subcontracting other companies and/or freelancers to do them provides access to the competence required for a given task with no long-term commitment to the individuals providing the service.

\section{The work situation of individuals}

From the preceding overview, it can be concluded that individual translators and interpreters can be either employed as staff-in an LSP or an in-house language service- or be selfemployed, as freelancers or with their own businesses. It is often claimed that freelance work predominates in translation today, but it is difficult to pinpoint the exact extent of this compared to in-house translation. After reviewing a number of studies from different countries, Pym et al. $(2012,89)$ conclude that "[t]he weighted average of the above figures [from the quoted studies] suggests that the general proportion of freelancers is around 78.4 percent." This figure is the same as the proportion of respondents to a more recent international survey about the ergonomics of translation who reported that they were freelancers (see Ehrensberger-Dow et al., forthcoming).

There were no studies from Sweden among those reviewed by Pym et al. (2012), but responses to a recent questionnaire among non-literary translators in Sweden and reported in Englund Dimitrova (2015b, 14-15) revealed even higher figures. ${ }^{4}$ Results showed that as many as $84 \%$ of the state-authorized and $90 \%$ of the non-authorized translators do translation work as part of their own registered businesses, but also that many of them do their translation work within more than one form of employment (e.g., on their own account or for an LSP,

\footnotetext{
${ }^{4}$ The questionnaire was designed to elicit translators' views on the present system of translator authorization in Sweden, but background data, such as on the form of employment and the extent of translation work, were also collected. The authorized translators $(\mathrm{N}=219)$ were contacted directly via email, with a response rate of $56.7 \%$. The non-authorized translators $(\mathrm{N}=245)$ were contacted through the webpage of the professional organization of non-literary translators, which has about 1100 members.
} 
depending on the assignment). Only $7 \%$ of the authorized and $4 \%$ of the non-authorized translators responding to this questionnaire do translation work as in-house translators (e.g., in translation agencies/LSPs or in the DGT). ${ }^{5}$

A consequence of outsourcing and freelancing is often part-time work. Indeed, regarding the extent of part-time translation work, Pym et al. conclude:

We might thus surmise that the level of part-time remunerated translation activity is about 60 percent in general, although this figure can be much lower (or higher) depending on the market segment surveyed or the kinds of questions asked.

(Pym et al. 2012, 88)

Once again, figures from the Swedish questionnaire show a similar tendency (see Englund Dimitrova 2015b, 14). Among authorized translators, 41\% report working with translation half-time or less, whereas only $26 \%$ of the non-authorized translators report working halftime or less. Thus, interestingly, translation is more clearly a main professional occupation among the non-authorized translators.

For the individual translator, especially if she is a freelancer, the system of outsourcing has the consequence that a number of decisions regarding work conditions, pay, and quality assessment are taken by a mediating body (i.e., the agency or LSP). It also means that there is usually no direct contact with the end user of the translation, since everything is channeled through the agency or LSP (see Olohan and Davitti 2015, 7; Risku et al. 2016, 14). Dunne (2012) discusses the possible negative consequences of the lack of direct contact with the translation buyer (including the lack of any direct feedback) for the development of the translator's competence and, ultimately, attainment of expertise.

It can be assumed that the task(s) of the translator in the modern translation industry depend to a large extent upon where she finds herself in the organizational structure outlined above. If she is at the last node in the hierarchy (e.g., in her own one-person business), it is more likely that her main, or only, task is translating texts. If she is at a higher node in the hierarchy, such as in an LSP firm, her job may consist of a mixture of different tasks, not only translating but also revising or reviewing others’ translations, project management, etc.

\footnotetext{
5 The mode of distribution might have precluded accurate representation of the in-house translators, however. The most recent official information from the European Commission (DGT 2014) mentions that of the 2,255 employed translators, 80 were of Swedish nationality. There is of course no one-to-one correspondence between nationality and combination of working languages. Some of the 100 translators of Finnish nationality can be assumed to have Swedish as one of their working languages, and among other nationalities, there are most certainly a number of translators with Swedish in their working combination.
} 
Clearly, the situational level of professional translation has undergone very important changes in a short time. Regarding organizational development, it could be argued that the changed position of the individual translator disproves some of the tenets of Skopos theory. Although Reiss and Vermeer (1984) acknowledged the existence of other actors in the process, they were very explicit in stressing the translator as expert in the process (quoted here from the English translation):

[...] the translator's role in the process of translational action: he is the one who ultimately decides what is translated or interpreted, when and how, on the basis of his knowledge of the source and target cultures and languages.

(Reiss and Vermeer 2013, 78; our emphasis)

The fact that, as specified in the EN15038:2006 and ISO 17100:2015 standards, translations are now as a rule revised by someone other than the translator makes the validity of the above claim doubtful. Kinnunen draws a similar conclusion regarding the relevance of HolzMäntääri’s (1984) concept of the coordinating role of translators:

Many translators today cannot plan their activities in cooperation with the initiator or commissioner, so are unable to act in the coordinating role of an expert with their own responsibilities.

(Kinnunen 2013, 84; our translation) $^{6}$

Jääskeläinen, Kujamäki, and Mäkisalo $(2011,153)$ attribute this change to the translation industry, which they claim has limited the translator's freedom of action by "assigning translators [...] the role of language decoders (e.g., localisation) or exploited mass-producers of text (e.g., subtitling).”

The image of the solitary translator can be said to have been supported and confirmed by much of the early research on the translation process. One reason for this is that the earliest process-oriented studies were done at a time when ICT was not as developed or as readily deployed in translation work as it is today. Indeed, the "lonely translator" is still found in much of the current cognitively-oriented research on the translation process. One reason is the experimental nature of much of that research, which necessitates research designs without confounding variables - to the extent that is even possible-and where the question of ecological validity is sometimes of secondary importance (see Gile 2016 for an overview). This image may still be true to some extent today, but perhaps mainly for students or the

\footnotetext{
${ }^{6}$ Original: "Viele Translatoren können heute ihre Tätigkeiten nicht in Kooperation mit dem Initiator oder dem Auftraggeber planen und damit in der koordinierenden Rolle eines Experten mit eigener Verantwortung handeln.” (Kinnunen 2013, 84)
} 
exceptional case of translators working entirely on their own account. In light of the changes to the organization of translation and interpreting work outlined in Section 3, considering both the cognitive and social levels has become a research imperative. Hence, some caution is advisable in generalizing from experimental studies in a laboratory setting to the specificities of professionals’ situated cognitive processing in the workplace.

\section{Acts and events - a combined perspective on the cognitive and situational levels?}

In conceptualizing the cognitive and situational levels of translation and interpreting, we have found the notions of 'act' and 'event' useful for exploring the interface between the levels. Initially introduced into Translation Studies by Toury (1995, 249; 2012, 67-68) and further expanded upon by Chesterman (2013, 155-157; 2015, 7-9), these terms can be applied to the objects of study of two research directions that have often been considered quite separate: the cognitive and the sociological. The translation act can be considered what happens in the human brain, the cognitive processes as reflected in observable practices, which has been the focus of much of the translation process research done in the past 20 years. The translation event, by contrast, is seen to involve not only the individual translators and interpreters, but also the agents, artefacts and organizations that impinge on their situated activities.

The study of translation or interpreting in situ involves a number of challenges (see also Ehrensberger-Dow 2014). A description of a given situation (e.g., a workplace) and its prominent features and work processes are clearly of value for enhancing our knowledge of new translation situations. The first six articles in this special issue, drawing on different theoretical and methodological frameworks, use various approaches to collect data in a diverse range of workplace settings far removed from the experimental conditions of much cognitively-based translation process research.

The first article of this special issue, by García Izquierdo, is a good example of how 'acts' and 'events' can be used as conceptual tools to delimit and define objects of study. It is interesting with respect to the interface for several reasons. For example, the paper has both descriptive and applied aims (see Holmes 1972/2000). The descriptive parts demonstrate the importance of taking into account the perspectives and knowledge of the various participants (professional experts in medicine, patients in need of information) for analyzing a given communicative situation with a multi-method design. Its applied components provide an example of how Translation Studies can help to meet pressing societal and community needs, in this case within the healthcare system, by suggesting appropriate information formats for patients and by designing terminological tools to assist translators in this type of work. 
From a very different culture and domain, the second article explores the temporal and spatial boundaries of the translation 'event'. In his contribution, Zhong describes the activist translation practice of a Chinese translator dedicated to spreading information on Robert's Rules of Order and promoting, in a Chinese village, knowledge about these rules. The on-site introduction to the villagers is referred to by the author of the article as 'live translation', and involves what can be seen as a presentation and continued work on the text that was previously translated by him and had already been published. However, the presentation by the translator is in oral form and is very strongly influenced by his audience's reactions. In adapting the existing translation, the translator together with his audience engage in shaping new knowledge.

The article by Van de Geuchte and Van Vaerenbergh considers the role of translators in multilingual text production in institutions by tracing the revision process in the DGT, the translation service of the European Commission. The question is, more specifically, the mutual dependency between the different versions of the source text and the target text(s) in a long process of text creation and translation, calling into question the boundaries between the translation 'act' and 'event'. Multilingual texts are seen as the result of complex distributed cognitive processes that are influenced by the context the text creators are working in. Translation is shown to form a part of a cooperative system of (both original and translated) text creation, to a large extent determined by the institution's policies and rules but also allowing some freedom of influence for translators.

In their article, Hokkanen and Koskinen present three case studies from different institutional settings, each involving the psychological-physiological concept of affect. They focus on individuals' perceptions and narratives to uncover the dialogue between the cognitive-personal and the social-interpersonal and to demonstrate how cognitive and social dimensions of translation and interpreting can be studied. Their main methodological framework, ethnography, necessarily involves the researcher themselves, as a research instrument, and this becomes particularly evident in the last of the authors' three case studies, where the researcher herself is also the research object (auto-ethnography). Through the presentation of three different studies as examples, this paper highlights the potential of different research methods for studying the cognitive and situational interface.

In their ethnographic study of an interpreting agency and public service interpreters, Dong and Turner show the strong impact of the agency's decisions and policies on both the working conditions of interpreters and on the interpreting situation as such. They claim that some of the organizational practices have tightened the control over individuals' autonomy 
and even put the interpreters at risk. Measures to enhance knowledge exchange and communication are identified as good practices, but there is room for improvement in meeting the ergonomic needs of the interpreters. Their findings support other research in indicating that the managerial imperative of standardizing work procedures has an impact upon people's behavior, by tightening control over planning and decision-making, thereby reducing interpreters' scope to adapt their activities to the demands of the situation.

Over-standardization can extend to the choice of technology by language service providers. Central procurement offices far removed from translators' daily reality and shared offices may preclude translators from deploying tools that have the potential to free up cognitive resources. Ciobanu discusses one such tool, Automatic Speech Recognition (ASR), and evaluates its current use for dictating translations directly into CAT tools and other aids on the basis of questionnaire and observational experimental data. His study indicates that translation with speech recognition might increase cognitive load during drafting and require more thorough revision processes. It also shows the complexities involved in integrating new tools into the workflow, since they are not always compatible or adapted to existing tools. Hence, in spite of their potential for increasing productivity and mitigating ergonomic issues at traditionally deskbound professional translation, such tools are not (yet) widely used.

Returning to the distinction between the act and the event, Muñoz takes a completely different stand in his article, offering a critical discussion of the two concepts and questioning their theoretical underpinnings. Proceeding from Chesterman's (2013/2015) paper, Muñoz argues that the distinction between the two 'levels' is actually non-existent and that they are indistinguishable, since one is impossible without the other (and vice versa). He contends that the distinction made in some of the models discussed is misleading because it is based on a narrow cognitive view of thought as rational, disembodied, decontextualized, and isolated rather than as a socially-situated phenomenon. Hence he claims that entirely new models are necessary in order to do justice to understanding the complexity of the translation process and to continue to make progress in the field.

\section{Concluding remarks}

The recent and continuing developments in translation and interpreting practices, some of which are outlined in Sections 2 and 3, clearly pose important challenges to Translation Studies. Studying a changing reality requires a reassessment of viable theoretical perspectives and methodologies as well as the potential introduction of new research methods. The articles in this special issue all aim to contribute to this. Common to most of them is that the 
theoretical frameworks are drawn from a variety of disciplines and the core of Translation Studies plays a less dominant role. Reflecting recent developments in Translation Studies and related disciplines, though, the empirical contributions all employ more than one research method or data collection method to capture the complexity of their research object. By offering insights into diverse translation and interpreting situations and their consequences for individual and collective cognition, we hope that this special issue will inspire many more researchers to explore the dynamics of the interface between the cognitive and situational levels in translation and interpreting.

\section{References}

Alonso, Elisa, and Elisa Calvo. 2015. "Developing a Blueprint for a Technology-mediated Approach to Translation Studies." Meta 60(1): 135-157.

Alves, Fabio, and Tânia Liparini Campos. 2009. "Chains of Cognitive Implication in Orientation and Revision during the Translation Process: Investigating the Impact of Translation Memory Systems in the Performance of Professional Translators.” Current Issues in Language Studies 1: 75-95.

Angelelli, Claudia V. 2004. Revisiting the Interpreter's Role. Amsterdam and Philadelphia: John Benjamins.

Angelelli, Claudia V. 2014. "Interpreting in the Healthcare Setting: Access in Cross-Linguistic Communication.” In The Routledge Handbook of Language and Health Communication, edited by Heidi Hamilton, and Silvia Chou, 573-585. London and New York: Routledge.

Antonini, Rachele. 2010. "Child Language Brokering: Trends and Patterns in Current Research.” mediAzioni 10: 1-23. Accessed May 16, 2016. http://www.mediazioni.sitlec.unibo.it/index.php/no-10-special-issue2010.html

Austermühl, Frank. 2001. Electronic Tools for Translators. Manchester: St. Jerome.

Austermühl, Frank. 2011. "The Technical Infrastructure of a Translator's Home Office.” In Übersetzung translation - traduction. Ein internationales Handbuch zur Übersetzungsforschung. An International Encyclopedia of Translation Studies. Encyclopédie internationale de la recherche sur la traduction, edited by Harald Kittel, Armin P. Frank, Norman Greiner, and Theo Hermans, 2642-2651. Berlin: De Gruyter.

Berk-Seligson, Susan. 1990. The Bilingual Courtroom. Court Interpreters in the Judicial Process. Chicago: The University of Chicago Press.

Biau Gil, José Ramón and Anthony Pym. 2006. ”Technology and Translation.” In: Translation Technology and Its Teaching, edited by Anthony Pym, Alexander Perestrenko, and Bram Starink, 5-19. Tarragona: Intercultural Studies Group, Universitat Rovira i Virgili.

Bower, Kathryn. 2015. “Stress and Burnout in Video Relay Service (VRS) Interpreting.” Journal of Interpretation 24(1): Article 2. Accessed May 10, 2016. http://digitalcommons.unf.edu/joi/vol24/iss1/2.

Bowker, Lynn. 2005. "Productivity vs Quality? A Pilot Study on the Impact of Translation Memory Systems.” Localisation Focus 4(1): 13-20.

Chernov, Sergei. 2016. “At the Dawn of Simultaneous Interpreting in the USSR: Filling some Gaps in History.” In New Insights in the History of Interpreting, edited by Kayoko Takeda and Jesús Baigorri Jalón, 167192. Amsterdam and Philadelphia: John Benjamins.

Chesterman, Andrew. 2013/2015. “Models of What Processes?” Translation and Interpreting Studies 8(2): 155-168 [Reprinted in Benjamins Current Topics 77, 7-20. Amsterdam and Philadelphia: John Benjamins].

Chevalier, Aline, and Maud Kicka. 2006. "Web Designers and Web Users: Influence of the Ergonomic Quality of the Web Site on the Information Search.” International Journal of Human-Computer Studies 64: 10311048.

Christensen, Tina P. 2011. "Studies on the Mental Processes in Translation Memory-Assisted Translation - the State of the Art.” Trans-Kom 4(2): 137-160. Accessed May 10, 2016, from http://www.transkom.eu/bd04nr02/trans-kom_04_02_02_Christensen_Translation_Memory.20111205.pdf.

Christensen, Tina P., and Anne Gram Schjoldager. 2010. “Translation-Memory (TM) Research: What Do We Know and How Do We Know It?” Hermes-Journal of Language and Communication Studies 44: 89-101.

Costa, Hernani, Gloria Corpas Pastor, and Isabel Durán Muñoz. 2014. “Technology-Assisted Interpreting.” Multilingual April/May 2014: 27-32. 
DePalma, Donald A., Hélène Pielmeier, Stephen Henderson, and Robert G. Stewart. 2015. The Language Services Market: 2015. Cambridge, MA: Common Sense Advisory.

DGI. 2015. Interpretation in Figures. Brussels: European Commission. Accessed May 10, 2016. http://ec.europa.eu/dgs/scic/docs/about_dg_int/statistics-brochure.pdf.

DGT. 2014. Translation in Figures. Brussels: European Commission. Accessed May 10, 2016. http://ec.europa.eu/dgs/translation/whoweare/translation_figures_en.pdf.

Dragsted, Barbara. 2006. “Computer-Aided Translation as a Distributed Cognitive Task.” Pragmatics \& Cognition 14(2): 443-464.

Dunne, Keiran J. 2012. “The Industrialization of Translation. Causes, Consequences and Challenges.” Translation Spaces 1: 143-168.

Ehrensberger-Dow, Maureen. 2014. "Challenges of Translation Process Research at the Workplace.” MonTI Monographs in Translation and Interpreting Special Issue 1: 355-383. http://rua.ua.es/dspace/bitstream/10045/43732/1/MonTI_2014_Special_Issue_13.pdf.

Ehrensberger-Dow, Maureen, Birgitta Englund Dimitrova, Severine Hubscher-Davidson, and Ulf Norberg (eds). 2013/2015. Describing Cognitive Processes in Translation: Acts and Events, Special issue of Translation and Interpreting Studies 8(2). [Reprinted in Benjamins Current Topics 77. Amsterdam and Philadelphia: John Benjamins.]

Ehrensberger-Dow, Maureen, Andrea Hunziker Heeb, Gary Massey, Ursula Meidert, Silke Neumann, and Heidrun Becker. Forthcoming. "An International Survey of the Ergonomics of Professional Translation.” ILCEA Revue de l'Institut des Langues et des Cultures d'Europe et d'Amérique.

Ehrensberger-Dow, Maureen, and Gary Massey. 2013. "Indicators of Translation Competence: Translators' Self-Concepts and the Translation of Titles.” Journal of Writing Research 5(1): 103-131. DOI: 10.17239/jowr-2013.05.01.5.

Ehrensberger-Dow, Maureen, and Gary Massey. 2014. “Cognitive Ergonomic Issues in Professional Translation.” In The Development of Translation Competence. Theories and Methodologies from Psycholinguistics and Cognitive Science, edited by John W. Schwieter, and Aline Ferreira, 58-86. Newcastle upon Tyne: Cambridge Scholars.

Ehrensberger-Dow, Maureen, and Sharon O’Brien. 2015. Ergonomics of the Translation Workplace: Potential for Cognitive Friction. Special Issue of Translation Spaces 4(1): 9-118. DOI :10.1075/ts.4.1.05ehr.

Elia. 2016. Language Industry Survey Report - Expectations and Concerns of the European Language Industry. European Language Industry Association. Accessed May 10, 2016. http://www.eliaassociation.org/news.php\#e82.

Elimam, Ahmed S. 2007. "The Impact of Translation Memory Tools on the Translation Profession.” Translation Journal 11(1). Accessed May 10, 2016, from http://translationjournal.net/journal/39TM.htm.

EN 15038:2006. Translation Services-Service Requirements. Brussels: European Committee for Standardization.

Englund Dimitrova, Birgitta. 2005. Expertise and Explicitation in the Translation Process. Amsterdam and Philadelphia: John Benjamins.

Englund Dimitrova, Birgitta. 2015a. From Loner to Teamplayer. The Translator in a Changing Professional Landscape. Presentation at IATIS conference, July 2015, Belo Horizonte, Brazil.

Englund Dimitrova, Birgitta. 2015b. Auktoriserad translator - kompetens och prov. Kartläggning och kunskapsunderlag. Stockholm: Kammarkollegiet. Accessed May 10, 2016. http://www.kammarkollegiet.se/dokument/auktoriserad-translator-kompetens-och-prov-kartl-ggning-ochkunskapsunderlag.

Englund Dimitrova, Birgitta, and Kenneth Hyltenstam (eds.). 2000. Language Processing and Simultaneous Interpreting. Interdisciplinary Perspectives. Amsterdam and Philadelphia: John Benjamins.

Enríquez Raído, Vanessa. 2013. “Teaching Translation Technologies 'Everyware’: Towards a Self-Discovery and Lifelong Learning Approach.” Revista Tradumàtica: tecnologies de la traducció 11: 275-285.

Eurofound. 2015. First Findings: Sixth European Working Conditions Survey. Brussels: EU Publications Office. DOI: 10.2806/59106.

Gambier, Yves. 2016. "Rapid and Radical Changes in Translation and Translation Studies.” International Journal of Communication 10: 887-906. DOI: 1932-8036/20160005.

García, Ignacio. 2009. “Beyond Translation Memory: Computers and the Professional Translator.” The Journal of Specialised Translation 12: 199-214.

Gile, Daniel. 2016. “Experimental Research.” In Researching Translation and Interpreting, edited by Claudia V. Angelelli, and Brian James Baer, 220-228. Abingdon: Taylor \& Francis Routledge.

Gouadec, Daniel. 2007/2010. Translation as a Profession. Amsterdam and Philadelphia: John Benjamins.

Hansen-Schirra, Silvia. 2012. "Nutzbarkeit von Sprachtechnologien für die Translation.“ Trans-Kom 5(2): 211226. Accessed May 10, 2016. http://www.trans-kom.eu/bd05nr02/trans-kom_05_02_02_HansenSchirra_Sprachtechnologien.20121219.pdf. 
Holmes, James S. 1972/2000. “The Name and Nature of Translation Studies.” In The Translation Studies Reader, edited by Lawrence Venuti, 172-185. London: Routledge.

Holz-Mänttäri, Justa. 1984. Translatorisches Handeln. Theorie und Methode (Suomalaisen Tiedeakatemian Toimituksia / Annales Academiæ Scientiarum Fennicæ B 226.) Helsinki: Suomalainen Tiedeakatemia.

Hönig, Hans G., and Paul Kussmaul. 1982. Strategie der Übersetzung: ein Lehr- und Arbeitsbuch (Tübinger Beiträge zur Linguistik 205). Tübingen: Narr.

ISO 2603:1998. Booths for Simultaneous Interpretation -- General Characteristics and Equipment. Geneva: International Organization for Standardization.

ISO 4043:1998. Mobile Booths for Simultaneous Interpretation -- General Characteristics and Equipment. Geneva: International Organization for Standardization.

ISO 13611:2014. Interpreting-Guidelines for community interpreting. Geneva: International Organization for Standardization.

ISO 17100:2015. Translation Services -- Requirements for Translation Services. Geneva: International Organization for Standardization.

Jääskeläinen, Riitta, Pekka Kujamäki, and Jukka Mäkisalo. 2011. “Towards Professionalism - or against It? Dealing with the Changing World in Translation Research and Translator Education.” Across Languages and Cultures 12(2): 143-156. DOI: 10.1556/Acr.12.2011.2.1.

Jiménez-Crespo, Miquel A. 2009. "The Effect of Translation Memory Tools in Translated Web Texts: Evidence from a Comparative Product-Based Study.” Linguistica Antverpiensia 8: 213-232.

Kelly, Nataly, and Donald DePalma. 2012. The Top 100 Language Service Providers. Cambridge MA: Common Sense Advisory. Accessed May 10, 2016. http://www.commonsenseadvisory.com/Portals/0/downloads/120531_QT_Top_100_LSPs.pdf.

Kinnunen, Tuija. 2013. "Translatorisches Handeln und die interprofessionale Kooperation im Kontext des Gerichtsdolmetschens in Finnland.” trans-kom 6(1): 70-91.

Kurz, Ingrid. 2002. "Physiological Stress Responses during Media and Conference Interpreting.” In Interpreting in the 21st Century, edited by Giuliana Garzone, and Maurizio Viezzi, 195-202. Amsterdam and Philadelphia: John Benjamins.

Kuznik, Anna, and Joan M. Verd. 2010. "Investigating Real Work Situations in Translation Agencies. Work Content and Its Components.” Hermes-Journal of Language and Communication Studies 44: 25-43.

Lafeber, Anne. 2012. Translation at Inter-Governmental Organizations. The Skills and Sets of Knowledge Required and the Implications for Recruitment Testing. PhD dissertation, Universitat Rovira i Virgili.

LeBlanc, Matthieu. 2013. "Translators on Translation Memory (TM). Results of an Ethnographic Study in Three Translation Services and Agencies.” Translation \& Interpreting 5(2): 1-13. DOI: ti.105202.2013.a01.

Mesa Lao, Bartolomé. 2014. “Gaze Behaviour on Source Texts: An Exploratory Study Comparing Translation and Post-editing.” In Post-editing of Machine Translation: Processes and Applications, edited by Sharon O'Brien, Laura Winther Balling, Michael Carl, Michel Simard, and Lucia Specia, 219-245. Newcastle upon Tyne: Cambridge Scholars.

Moorkens, Joss, and Sharon O’Brien. 2013. “User Attitudes to the Post-editing Interface.” Proceedings of MT Summit XIV workshop on post-editing technology and practice, 19-25. Allschwil: The European Association for Machine Translation.

O'Hagan, Minako (ed.). 2011. Translation as a Social Activity - Community Translation 2.0. Special issue of Linguistica Antverpiensia New Series - Themes in Translation Studies 10.

O’Brien, Sharon. 2012. “Translation as Human-computer Interaction.” Translation Spaces 1: 101-122.

O’Brien, Sharon, Minako O’Hagan, and Marian Flanagan. 2010. "Keeping an Eye on the UI Design of Translation Memory: How Do Translators Use the 'Concordance' Feature?” In Proceedings of the $28^{\text {th }}$ European Conference on Cognitive Ergonomics, edited by Willem Paul Brinckman, and Mark Neerincx, 187-190. Delft: Delft University of Technology.

Olohan, Maeve, and Elena Davitti. 2015. "Dynamics of Trusting in Translation Project Management: Leaps of Faith and Balancing Acts.” Journal of Contemporary Ethnography, 1-26. DOI: 10.1177/0891241615603449.

Orlando, Marc. 2014. “A Study on the Amenability of Digital Pen Technology in a Hybrid Mode of Interpreting: Consec-Simul with Notes.” Translation \& Interpreting 6(2): 39-54. DOI: 10.12807/ti.106202.2014.a03.

Palvalin, Miikka, Antti Lönnqvist, and Maiju Vuolle. 2013. "Analysing the Impacts of ICT on Knowledge Work Productivity." Journal of Knowledge Management 17(4): 545-557. DOI: 10.1108/JKM-03-20130113.

Pym, Anthony. 2011. "What Technology Does to Translating.” Translation \& Interpreting 3(1): 1-9. Accessed May 10, 2016. http://www.trans-int.org/index.php/transint/article/view/121.

Pym, Anthony. 2013. “Translation Skill-Sets in a Machine-Translation Age.” Meta 58(3): 487-503. 
Pym, Anthony, François Grin, Claudio Streddo, and Andy L. J. Chan. 2012. The Status of the Translation Profession in the European Union. Final Report (= Studies on Translation and Multilingualism, 7/2012). Brussels: European Commission.

Reiss, Katharina, and Hans Vermeer. 1984. Grundlegung einer allgemeinen Translationstheorie. Tübingen: Niemeyer.

Reiss, Katharina, and Hans J. Vermeer. 2013. Towards a General Theory of Translational Action. Skopos Theory Explained [Translated from the German by Christiane Nord]. London and New York: Routledge.

Risku, Hanna. 2002. “Situatedness in Translation Studies.” Cognitive Systems Research 3: 523-533.

Risku, Hanna. 2007. “The Role of Technology in Translation Management.” In Doubts and Directions in Translation Studies, edited by Yves Gambier, Miriam Shlesinger, and Radegundis Stolze, 85-97. Amsterdam and Philadelphia: John Benjamins. DOI:10.1075/btl.72.11ris

Risku, Hanna. 2010. “A Cognitive Scientific View on Technical Communication and Translation. Do Embodiment and Situatedness Really Make a Difference?” Target 22(1): 94-111.

Risku, Hanna. 2014. "Translation Process Research as Interaction Research. From Mental to Socio-Cognitive Processes.” In Minding Translation, edited by Ricardo Muñoz Martín, 331-353. MonTI Monographs in Translation and Interpreting Special Issue 1.

Risku, Hanna, and Angela Dickinson. 2009. "Translators as Networkers: The Role of Virtual Communities.” Hermes-Journal of Language and Communication Studies 42: 49-70.

Risku, Hanna, Regina Rogl, and Christina Pein-Weber. 2016. "Mutual Dependencies: Centrality in Translation Networks.” The Journal of Specialised Translation 25: 1-22.

Risku, Hanna, and Florian Windhager. 2013/2015. "Extended Translation. A Sociocognitive Research Agenda.” Target 25(1): 33-45. [Reprinted in Benjamins Current Topics 72, 35-47. Amsterdam and Philadelphia: John Benjamins.]

Roziner Ilan, and Miriam Shlesinger. 2010. "Much Ado about Something Remote. Stress and Performance in Remote Interpreting.” Interpreting 12(2): 214-247.

Screen, Benjamin Alun. 2016. "What Does Translation Memory Do to Translation? The Effect of Translation Memory Output on Specific Aspects of the Translation Process.” Translation \& Interpreting 8(1): 1-18. DOI: 10.12807/ti.108201.2016.a01.

Susam-Saraeva, Şebnem, and Luis Pérez González (eds.). 2012. Non-Professionals Translating and Interpreting: Participatory and Engaged Perspectives. Special issue of The Translator 18(2).

Szameitat, André J., Jan Rummel, Diane P. Szameitat, and Annette Sterr. 2009. "Behavioral and Emotional Consequences of Brief Delays in Human-Computer Interaction.” International Journal of HumanComputer Studies 67: 561-570.

Taravella, AnneMarie, and Alain O. Villeneuve. 2013. “Acknowledging the Needs of Computer-Assisted Translation Tools Users: The Human Perspective in Human-Machine Translation.” The Journal of Specialised Translation 19: 62-74.

Teixeira, Carlos S. C. 2014. The Impact of Metadata on Translator Performance: How Translators Work with Translation Memories and Machine Translation. PhD dissertation, Universitat Rovira i Virgili. Accessed May 10, 2016. http://hdl.handle.net/10803/285838.

Torres Hostench, Olga, José Ramon Biau Gil, Pilar Cid Leal, Adriá Martín Mor, Bartolomé Mesa Lao, Mariana Orozco Jutorán, and Pilar Sanchez Gijón. 2010. "TRACE: Measuring the Impact of CAT Tools on Translated Texts.” In Linguistic and Translation Studies in Scientific Communication, edited by Maria Lluisa Gea Valor, Isabel García Izquierdo, and Maria José Esteve, 255-276. Bern: Peter Lang.

Toury, Gideon. 1995. Descriptive Translation Studies - and Beyond. Amsterdam and Philadelphia: John Benjamins.

Toury, Gideon. 2012. Descriptive Translation Studies-and Beyond. Revised edition. Amsterdam and Philadelphia: John Benjamins.

Tuch, Alexandre N., Javier A. Bargas-Avila, Klaus Opwis, and Frank H. Wilhelm. 2009. "Visual Complexity of Websites: Effects on Users’ Experience, Physiology, Performance, and Memory.” International Journal of Human-Computer Studies 67: 703-715.

UN 2011. Measuring the Impacts of Information and Communication Technology for Development. UNCTAD Current Studies on Science, Technology and Innovation, no. 3.

Wadensjö, Cecilia. 1998. Interpreting as Interaction. London: Longman.

Zetsche, Jost. 2007. "Creating the Ideal Word Processing Environment in Translation Environment Tools." Translation Journal 11(4). Accessed May 10, 2016. http://translationjournal.net/journal/42toolbox.htm. 